\title{
STUDI KUALITAS PELAYANAN PADA SOSIAL MEDIA INSTAGRAM NINJA XPRESS TERHADAP PENINGKATAN CITRA PERUSAHAAN
}

\author{
Aditya Krisna Putri ${ }^{1}$, Yani Hendrayani ${ }^{2}$, Uljanatunnisa ${ }^{3}$ \\ Program Studi Ilmu Komunikasi, Fakultas Ilmu Sosial dan Ilmu Politik \\ Universitas Pembangunan Nasional "Veteran" Jakarta \\ Email: adityakrisnaputri@gmail.com
}

\begin{abstract}
ABSTRAK
Penelitian ini membahas tentang studi kualitas pelayanan pada sosial media instagram Ninja Xpress terhadap peningkatan citra perusahaan. Tujuan penelitian ini untuk mengetahui besarnya pengaruh kualitas pelayanan terhadap peningkatan citra perusahaan pada jasa pengiriman Ninja Xpress. Model yang digunakan dalam penelitian ini adalah Model Pembentukan Citra. Metode yang digunakan adalah kuantitatif. Penelitian ini menggunakan metode survei dengan kuesioner. Populasi dalam penelitian ini adalah followers Instagram @NinjaXpress, untuk sampel menggunakan rumus Yamane yang kemudian didapatkan sebanyak 99 responden. Teknik penarikan sampel yang digunakan dalam penelitian ini adalah teknik purposive sampling. Hasil penelitian menunjukan bahwa hasil uji korelasi variabel X (kualitas pelayanan) terhadap variabel Y (citra perusahaan) sebesar 0,821. Berdasarkan hasil perhitungan koefisien determinasi didapatkan hasil adanya pengaruh variabel $\mathrm{X}$ terhadap variabel $\mathrm{Y}$ sebesar $67,4 \%$, yang berarti memiliki pengaruh yang signifikan antara variabel $\mathrm{X}$ terhadap variabel $\mathrm{Y}$. Hasil uji $\mathrm{t}$ didapatkan $\mathrm{t}$ hitung $>\mathrm{t}$ tabel yaitu thitung 14,184 > t tabel 1.661, maka dapat disimpulkan H0 ditolak dan Ha diterima. Kesimpulan dari penelitian bahwa terdapat pengaruh yang sangat kuat antara kualitas pelayanan terhadap citra perusahaan pada jasa pengiriman Ninja Xpress. Saran dari penelitian ini bahwa akun Instagram Ninja Xpress harus selalu aktif dalam berinteraksi dengan customernya dan selalu membuat inovasi terbaru pada unggahan konten Instragram.
\end{abstract}

Kata kunci : Kualitas Pelayanan, Model Pembentukan Citra, Citra Perusahaan

\section{QUALITY OF SERVICE STUDY IN SOCIAL MEDIA INSTAGRAM OF NINJA XPRESS AGAINST IMPROVING THE CORPORATE IMAGE}

\begin{abstract}
This study discusses quality of service study in social media instagram of Ninja Xpress against improving the corporate image. The purpose of this research is to know the magnitude of the influence quality of service against improving corporate image on delivery service of Ninja Xpress. The model used in this study is a model of the formation of images. The method used is quantitative. This research using survey method by using a questionnaire. The population in this research is a followes of Ninja Xpress's Instagram, for the sample Yamane formula using which then obtained as many as 99 of respondents. Sample withdrawal techniques used in this research is purposive sampling technique. The research results showed that test results correlation variable $X$ (quality of service) against the variable $Y$ (the corporate image) of 0,821. Based on the results of the calculation of the coefficient of determination of the obtained results the presence of the influence of variables $X$ against $Y$ variables of 67,4\% it means the results of the influences is significant between variables $X$ against $Y$ variables. $T$ test results in apat $t$ calculate $>t$ table i.e. $t$ calculate 14,184 > 1,661 table t, then it can be inferred HO is rejected and the Ha are received. The conclusion from research that Instagram of Ninja Xpress account must always be active in interacting with their customers and making the latest innovations in Instagram content uploads.
\end{abstract}

Keywords: Quality of Service, Model of The Formation of Images, Corporate Image 
Korespondensi: Aditya Krisna Putri, S.I.Kom. Universitas Pembangunan Nasional "Veteran" Jakarta. Jl. RS Fatmawati, Pondok Labu, Jakarta 12450. No HP, Whatsapp : 089659494496. E-mail : adityakrisnaputri@ gmail.com

\section{PENDAHULUAN}

Kebutuhan masyarakat di Indonesia pada saat ini semakin bertambah dan mengikuti perkembangan zaman, persaingan dalam bidang usaha pun kian gencar dan tingkat konsumen semakin meningkat tiap tahunnya. Perusahaan yang mampu bersaing dalam pasar adalah perusahaan yang dapat menyediakan produk atau jasa bekualitas. Hal ini dimaksudkan agar seluruh barang atau jasa yang di tawarkan akan menarik perhatian di mata masyarakat dan mendapatkan hati masyarakat selaku konsumen dalam memilih barang dan jasa. Dalam membeli suatu produk atau jasa, konsumen tidak ingin memilih suatu produk dengan tidak memenuhi standart.

Terlebih pada saat ini sedang trendnya bisnis online, dalam kegiatan berbisnis online saat ini sudah sangat berkembang dengan cepat, kemudahan dalam menawarkan dan membeli suatu produk di situs-situs online membuat banyak masyarakat di Indonesia membeli produk secara online. Dalam hal ini jasa pengiriman barang sangat berperan penting terhadap kegiatan jual beli online sebagai media penyambung antara penjual dan pembeli dalam media pendistribusian barang.

Bisnis pengiriman barang merupakan salah satu bisnis yang sedang menjadi primadona di tanah air kita pada tahun ini. Peluang usaha ekspedisi pun semakin cerah yang disebabkan oleh pertumbuhan pasar e-commerce. Adanya sistem berbelanja melalui online ini mendukung hadirnya perusahaan-perusahaan jasa pengiriman barang atau kurir sehingga masyarakat dapat dengan mudah menikmati berbelanja di pasar e-commerce. Dengan mengikuti perkembangan jaman, bisnis pengiriman atau startup logistik seperti Ninja Xpress, Go Send, Iruna dan lainnya menawarkan jasa pengiriman barang yang sudah berbasis teknologi digital.

Dalam hal pengiriman paket dituntut untuk selalu meningkatkan kualitas pelayanan guna mencapai kepercayaan dan loyalitas konsumen. Beberapa upaya untuk meningkatkan kualitas pelayanan (customer satisfactions) yaitu dapat melalui perluasan jangkauan, peningkatan kecepatan waktu tempuh yang cepat dan terjamin serta ketanggapan dalam pelayanan. Peningkatan layanan untuk menyikapi persaingan yang semakin kompetitif juga ditunjukkan dengan hadirnya berbagai jasa pengiriman selain Ninja Xpress. Beberapa diantaranya adalah Indo Ekspedisi, PT. NCS, PT. TIKI Online, JNE Express, PT. Repex Perdana Internasional bekerjasama dengan Federal Express, DHL, dan lainnya yang siap bertarung kualitasnya agar memiliki daya saing tinggi.

Dilansir dari website resellerdropship.com pada Juni 2019, Ninja Xpress merupakan jasa pengiriman dari Ninja Van yang diluncurkan pada tahun 2014. Ninja Van sendiri merupakan perusahaan pengiriman ekspress berbasis teknologi yang menyediakan layanan pengiriman berbasis teknologi di Asia Tenggara. Layanan Ninja Xpress dapat dinikmati dibeberapa wilayah di Indonesia seperti Pulau Sumatera, Pulau Jawa, Pulau 
Lombok, Pulau Bali dan Pulau Sulawesi. Ninja Xpress telah bekerjasama dengan beberapa $e$ commerce antara lain Bukalapak, Tokopedia, Hijup, MatahariMall, Lazada, SaleStock, Blibli dan banyak lagi.

Ninja Xpress sebagai perusahaan yang bergerak dalam bidang jasa dituntut untuk memberikan pelayanan yang berkualitas kepada pelanggannya. Keputusan pelanggan untuk menggunakan jasa pengiriman barang terjadi apabila kualitas pelayanan pada perusahaan pengiriman barang tersebut sesuai dengan apa yang diharapkan pelanggan. Dilansir dari artikel ainoru.com yang di unggah pada Februari 2019, ada beberapa jasa pengiriman (ekspedisi) terbaik dan terpopuler di Indonesia, yaitu: JNE, J\&T, Pos Indonesia, TIKI, Si Cepat Ekspres dan Lion Parcel.

Ninja Xpress tidak masuk dalam kategori ekspedisi terbaik karena masih terbilang baru di kalangan ekspedisi sehingga belum bisa mengetahui raport Ninja Xpress. Berkaitan dengan ekspedisi yang terbilang masih baru tentu tidak bisa lepas dari kekurangan yang dimiliki Ninja Xpress, seperti minimnya informasi mengenai barang menjadi salah satu faktor penghambat customer dalam mencari informasi tentang keberadaan barang yang di antar maupun barang yang di pick up.

Merujuk pada permasalahan yang ada, maka peneliti memfokuskan meneliti mengenai kualitas pelayanan terhadap citra perusahaan pada jasa pengiriman Ninja Xpress yang telah merasakan langsung pelayanan yang diberikan Ninja Xpress.

\section{METODE PENELITIAN}

\section{Jenis dan Sifat Penelitian}

Penelitian ini menggunakan jenis penelitian survei, untuk mendapatkan datanya penulis menggunakan kuesioner yang disebar lalu data tersebut diukur sehingga dapat diidentifikasikan hubungan antara variabel. Penelitian ini bersifat eksplanatif, karena peneliti ingin melihat pengaruh sebab akibat antara dua variabel yaitu variabel kualitas layanan dan citra perusahaan.

\section{Populasi}

Populasi yang dipilih dalam penelitian ini adalah followers Ninja Xpress di Instagram yang berjumlah 16.700 orang sehingga dari rataan ini dapat menjadi sampel. Alasan peneliti melakukan penelitian kepada followers Ninja Xpress di Instagram adalah karena Ninja Xpress sering berinteraksi dengan followersnya melalui kolom komentar sehingga peneliti dapat dengan mudah berinteraksi dengan followersnya melalui kolom komentar maupun melalui direct message.

\section{Sampel}

Teknik pengambilan sampel yang akan digunakan adalah Teknik Non Probability Sampling artinya anggota populasi tidak memiliki kesempatan yang sama untuk menjadi sampel. Teknik yang digunakan yaitu Teknik Pengambilan Sampel Purposive. Teknik tersebut menggunakan atau menentukan kriteria khusus terhadap sampel. Dalam penelitian ini sampel yang diambil memiliki kriteria khusus yaitu pengguna atau customer Ninja Xpress.

Penarikan sampel pada penelitian ini adalah dengan menggunakan rumus Yamane dengan batas 
error $10 \%$. Dari besarnya populasi yang berjumlah 15.700 orang, dihasilkan sampel sebesar maka jika dibulatkan akan dipilih 99 orang sampel, dengan proses hitung seperti berikut ini:

\section{Keterangan :}

$$
n=\frac{N}{N d^{2}+1}
$$

$$
\begin{aligned}
\mathrm{n}= & \text { Besarnya ukuran sampel. } \\
\mathrm{N}= & \text { Besarnya populasi. } \\
\mathrm{d}= & \text { Kelonggaran ketidak telitian } \\
& \text { karena kesalahan pengambilan }
\end{aligned}
$$
sampel yang dapat ditolerir. Pada penelitian ini, penulis menggunakan batas toleransi $10 \%$.

$$
\begin{gathered}
n=\frac{N}{N d^{2}+1} \\
n=\frac{16.700}{16.700 \times(10 \%)^{2}+1} \\
n=\frac{16.700}{16.700 \times(0,01)+1} \\
n=\frac{16.700}{168} \\
n=99,40 \text { dibulatkan menjadi } 99 .
\end{gathered}
$$

\section{Metode Pengumpulan Data}

Sumber data yang diperoleh dalam penelitian ini didapat dari dua cara yaitu data primer adalah diperoleh melalui serangkaian observasi dan penyebaran kuesioner kepada responden. Dan data sekunder adalah diperoleh dengan menggunakan studi litelatur yang dilakukan terhadap banyak buku dan diperoleh berdasarkan catatan-catatan yang berhubungan dengan penelitian selain itu peneliti menggunakan data yang diperoleh dari internet.

\section{Metode Analisis Data}

Analisis data merupakan kegiatan setelah data dari seluruh responden atau sumber data lain terkumpul. Penulis menggunakan program windows statistic for social science (SPSS) versi 25 dalam mengelola data yang telah di peroleh.

1. Uji Korelasi

Dalam analisis kolerasi yang dicari adalah koefisien kolerasi yaitu angka yang menyatakan derajat hubungan antara variabel independen (X) dengan variabel dependen (Y) atau untuk mengetahui kuat atau lemahnya hubungan antara variabel independen dengan variabel dependen.

Adapun rumus yang digunakan untuk mengukur atau menguji validitas dari kolerasi variabel penelitian ini adalah Rumus Pearson's Moment Sugiyono (2015, hlm 248) :

$$
\boldsymbol{r}_{x y}=\frac{n \cdot\left(\sum X Y\right)-\left(\sum X\right)\left(\sum Y\right)}{\left.\left.\sqrt{\left(n \cdot \sum_{X}{ }^{2}\right.}-\left(\sum X\right)^{2}\right) \cdot\left(n \cdot \sum_{Y} 2-\sum Y\right)^{2}\right)}
$$

Keterangan :

$r_{x y} \quad$ Koefisien korelasi X dan Y

$\mathrm{N}$ : Banyaknya subyek skor $\mathrm{X}$ dengan skor $\mathrm{Y}$ dengan berpasangan

$\sum_{X} 2$ : Jumlah skor yang dikuadratkan dari X

$\sum_{r} 2$ : Jumlah skor yang dikuadratkan dari $\mathrm{Y}$

$\sum X \quad$ : Jumlah skor dalam sebaran $\mathrm{X}$

$\sum Y \quad$ : Jumlah skor dalam sebaran $\mathrm{Y}$

$\sum X Y$ : Jumlah hasil skor $\mathrm{X}$ dengan skor $\mathrm{Y}$ yang berpasangan 


\section{Koefisien Determinasi}

Menjelaskan besarnya kontribusi yang diberikan variabel independent terhadap variabel dependent. Koefisien determinasi dihitung dengan cara mengkuadratkan hasil korelasi kemudian dikalikan 100\%. Seperti rumus:

$$
\mathrm{Kd}=\mathrm{r} 2 \times 100 \%
$$

Keterangan:

$\mathrm{Kd}=$ Koefisien determinasi

$\mathrm{R}=$ Koefisien korelasi

$\mathrm{Kd}=\mathrm{r} 2 \times 100 \%$

\section{Uji Regresi}

Regresi merupakan Menurut Sugiyono (2008: 261). Regresi merupakan suatu alat ukur yang digunakan untuk mengukur ada atau tidaknya hubungan antar variabel. Dalam analisis regresi, suatu persamaan regresi atau persamaan penduga dibentuk untuk menerangkan pola hubungan variabel-variabel apakah ada hubungan antara 2 (dua) variabel atau lebih. Hubungan yang didapat pada umumnya menyatakan h Hubungan fungsional antara variabel-variabel.

$$
Y=a+b X
$$

\section{Keterangan :}

$$
\begin{aligned}
\mathrm{Y}= & \text { Variabel tidak bebas } \\
\mathrm{X}= & \text { Variabel bebas } \\
\mathrm{a}= & \text { Nilai intercept (konstan) } \\
& \text { atau harga } \mathrm{Y} \text { bila } \mathrm{X}=0 \\
\mathrm{~b}= & \text { Koefisien regresi, yaitu angka } \\
& \text { peningkatan atau peningkatan } \\
& \text { atau penurunan variabel }
\end{aligned}
$$

dependen yang didasarkan pada variabel dependen. Bila $b(+)$ maka naik, bila $b(-)$ maka terjadi penurunan

4. Uji Hipotesis

Untuk menguji hipotesis penulis menggunakan Uji T. Uji T dikenal dengan uji parsial, yaitu untuk menguji bagaimana pengaruh masing-masing variabel bebasnya sacara sendirisendiri terhadap variabel terikatnya. Uji ini dapat dilakukan dengan membandingkan t hitung dengan t table atau dengan melihat kolom signifikansi pada masing-masing t hitung. Untuk menentukan Uji T penelitian ini menggunakan cara manual dan langkah-langkahnya sebagai berikut. Rumus Uji T sebagai berikut:

$$
\mathrm{t}=r \frac{\sqrt{n-2}}{\sqrt{1-r^{2}}}
$$

Keterangan:

$\mathrm{r}=$ koefisiensi korelasi

$\mathrm{n}=$ jumlah responden $(\mathrm{n}-2=\mathrm{dk}$, derajat kebebasan)

\section{Waktu dan Lokasi Penelitian}

Waktu yang digunakan peneliti adalah dua bulan. Peneliti menggunakan satu bulan untuk mengumpulkan data dan untuk pengolahan data. Peneliti munggunakan google form untuk menyebarkan kuisioner pada followers Instagram Ninja Xpress.

\section{HASIL DAN PEMBAHASAN}

Hasil Penelitian

Pada penelitian ini, peneliti akan menyajikan data mengenai pernyataan sejumlah 31 butir dari kuesioner yang telah disebar kepada 99 
responden. Penyataan berjumlah 31 butir dengan rincian 18 butir pernyataan untuk mengukur variabel X (Kualitas Pelayanan) serta 13 butir lainnya digunakan untuk mengukur variabel $\mathrm{Y}$ (Citra Perusahaan). Berdasarkan hasil dari uji validitas dan uji reliabilitas yang sudah dilakukan, maka peneliti menggunakan 31 pernyataan valid dan sangat reliabel tersebut untuk disebarkan dan diisi oleh 99 responden.

Diketahui dari 99 responden yang berpartisipasi dalam penelitian ini mayoritas responden masih berusia muda dan terbanyak berusia 21-25 tahun sejumlah 48 orang dengan presentase $48,5 \%$. Sebanyak 65 responden dalam penelitian ini berjenis kelamin perempuan.

\section{Analisis Hasil Uji Koefisien Korelasi}

Peneliti melakukan analisis hasil uji korelasi untuk mengetahui hubungan antara Kualitas Pelayanan terhadap Citra Perusahaan pada Jasa Pengiriman Ninja Xpress. Uji ini dilakukan dengan menggunakan SPSS 25.

\section{Tabel 1. Hasil Uji Koefisien Korelasi}

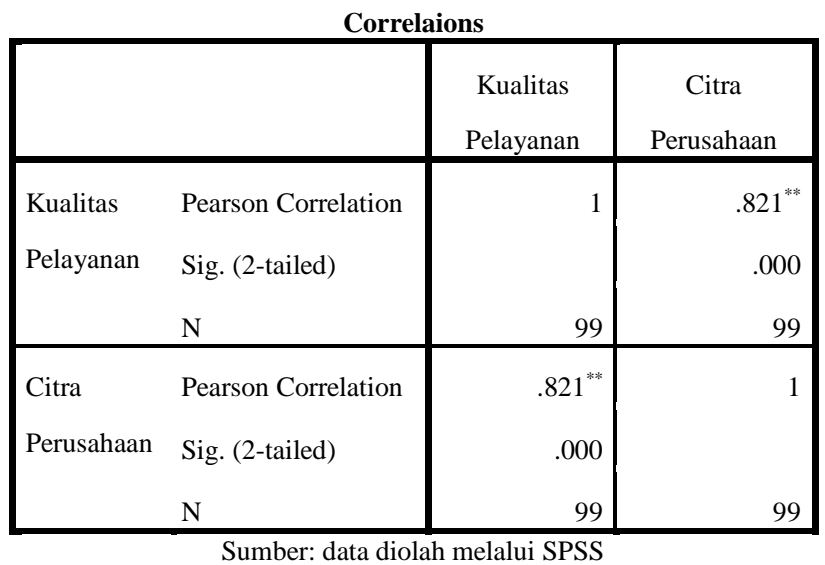

Tabel diatas adalah tabel uji korelasi dengan menggunakan SPSS for windows yang mana terdapat nilai korelasi $\mathrm{r}$ yaitu $=0.821$, nilai tersebut memiliki hubungan yang "sangat kuat" karena terletak diantara $0,800-1,000$, maka dapat disimpulkan bahwa antara kualitas pelayanan (Variabel X) terhadap citra perusahaan (Variabel Y) memiliki hubungan yang sangat kuat.

Angka koefisien korelasi pada hasil di atas bernilai positif, yaitu 0,821 sehingga hubungan kedua variabel tersebut bersifat searah (jenis hubungan searah), dengan demikian dapat diartikan bahwa semakin tinggi kualitas pelayanan Ninja Xpress maka semakin besar pengaruh citra perusahaan. Maka dapat disimpulkan bahwa hubungan antara pengaruh kualitas pelayanan (variabel $\mathrm{X}$ ) terhadap peningkatan citra perusahaan Ninja Xpress (variabel Y) memiliki hubungan yang sangat signifikan.

\section{Analisis Hasil Uji Koefisien Determinasi}

Tabel 2. Hasil Uji Koefisien Determinasi

\begin{tabular}{|c|r|r|r|r|}
\multicolumn{1}{|c|}{ Model Summary } \\
Model & $\mathrm{R}$ & R Square & $\begin{array}{c}\text { Adjusted R } \\
\text { Square }\end{array}$ & $\begin{array}{c}\text { Std. Error } \\
\text { of the } \\
\text { Estimate }\end{array}$ \\
\hline 1 & $.821^{\mathrm{a}}$ & .674 & .670 & 4.56097 \\
\hline
\end{tabular}

Sumber: data diolah melalui SPSS

Dalam melihat seberapa besar kontribusi pengaruh kualitas pelayanan mempengaruhi terhadap peningkatan citra perusahaan Ninja Xpress, harus dicari koefisien determinasi dihitung dengan cara mengkuadratkan hasil korelasi kemudian dikalikan dengan 100\% seperti rumus sebagai berikut :

$$
\mathrm{Kd}=\mathrm{r}^{2} \mathrm{x} 100 \%
$$


Keterangan :

Kd : Koefisien Determinasi

$\mathrm{r}$ : Koefisien Korelasi

Maka :

$$
\begin{aligned}
\mathrm{Kd} & =0,821^{2} \times 100 \% \\
& =0,674 \times 100 \% \\
& =67,4 \%
\end{aligned}
$$

Berdasarkan perhitungan hasil dari determinasi diketahui nilai Korelasi $(R)=0,821$ dan nilan $\mathrm{R}$ square (yang merupakan penguadratan nilai korelasi) yaitu $=67,4 \%$. Maka dapat disimpulkan 67,4\% citra perusahaan (Variabel Y) ditentukan oleh pengaruh kualitas pelayanan (Variabel X), dan sisanya sejumlah $32,6 \%$ ditentukan oleh faktor lain yang tidak diteliti. Hal ini menunjukkan bahwa kualitas pelayanan merupakan salah satu faktor yang dapat mempengaruhi peningkatan citra perusahaan. Untuk bersaing dengan kompetitor lain, maka diperlukan kualitas pelayanan lebih baik dan promosi pengiriman dengan harga yang lebih murah. Dengan begitu, customer akan membandingkan faktor-faktor tersebut antara Ninja Xpress dengan jasa pengiriman atau ekspedisi lain yang merupakan kompetitornya.

\section{Analisis Hasil Uji Regresi}

Tabel 3. Uji Regresi

\section{Coefficients $^{a}$}

\begin{tabular}{|c|c|c|c|c|c|}
\hline \multirow{2}{*}{ Model } & \multicolumn{2}{|c|}{$\begin{array}{c}\text { Unstandardized } \\
\text { Coefficients }\end{array}$} & $\begin{array}{c}\text { Standardize } \\
\mathrm{d} \\
\text { Coefficients }\end{array}$ & $\mathrm{t}$ & Sig \\
\cline { 2 - 5 } & $\mathrm{B}$ & Std. Error & Beta & & \\
\hline \multirow{2}{*}{$\begin{array}{c}\text { (Constant) } \\
\text { Kualitas }\end{array}$} & 5.460 & 2.460 & & 2.220 & .02 \\
Pelayanan & .624 & .044 & .821 & 14.14 & .00 \\
& & & & 0 \\
\hline
\end{tabular}

Sumber: data diolah melalui SPSS Berdasarkan tabel diatas dapat diperoleh persamaan regresi dengan rumus berikut :

$$
\mathbf{Y}=\mathbf{a}+\mathbf{b X}
$$

Keterangan :

Y : Variabel tidak bebas

X : Variabel bebas

a : Nilai intercept (konstan) atau harga Y bila $X=0$

b : Koefisien regresi, yaitu angka peningkatan atau peningkatan atau penurunan variabel dependen yang didasarkan pada variabel dependen. Bila $b(+)$ maka naik, bila $b(-)$ maka terjadi penurunan.

$$
\text { Maka } Y=5.460+0.624 X
$$

Dapat disimpulkan bahwa koefisien regresi sebesar 0,624 X yang memiliki arti bahwa setiap penambahan satu kali untuk pengaruh kualitas pelayanan maka pengaruh citra perusahaan meningkat sebesar 0.624 .

\section{Analisis Hasil Uji Hipotesis}

Uji T dilakukan untuk menguji signifikasi koefisien koelasi variabel $\mathrm{x}$ dengan variabel $\mathrm{y}$. Pengujian hipotesis dapat dihitung dengan uji $\mathrm{T}$ dengan rumus sebagai berikut :

$$
\mathrm{t}=r \frac{\sqrt{n-2}}{\sqrt{1-r^{2}}}
$$

Keterangan:

$\mathrm{t}=$ uji signifikasi

$r$ = koefisiensi korelasi

$\mathrm{n}=$ jumlah responden $(\mathrm{n}-2=\mathrm{dk}$, derajat kebebasan) 
Maka :

$$
\begin{gathered}
=\frac{0,821 \sqrt{99-2}}{\sqrt{1-0,821^{2}}} \\
t=\frac{0,821 \times \sqrt{97}}{\sqrt{1-0,674}} \\
t=\frac{0,821 \times 9,848}{\sqrt{0,326}} \\
t=\frac{8,085}{0,570} \\
t=\mathbf{1 4 , 1 8 4}
\end{gathered}
$$

Penentuan signifikansi adalah dengan membandingkan $\mathrm{t}$ hitung dengan $\mathrm{t}$ tabel yaitu penentuan dari level of signification, dari t tabel nilainya ditentukan pada tingkat signifikansi 0,10 dan $\mathrm{df}=\mathrm{n}-2$, yaitu $99-2=97$. Dengan demikian, $\mathrm{t}$ tabel adalah 1,661. Berdasarkan perhitungan tersebut, hasil perhitungan $\mathrm{t}$ hitung $>\mathrm{t}$ tabel yaitu $14,184>1,661$, maka dapat disimpulkan Ho ditolak dan $\mathrm{Ha}$ diterima yang berarti terdapat pengaruh kualitas pelayanan terhadap citra perusahaan pada jasa pengiriman Ninja Xpress.

\section{Pembahasan}

Berdasarkan penelitian yang telah dilakukan penulis yaitu berjudul "Pengaruh kualitas pelayanan terhadap citra perusahaan pada jasa pengiriman Ninja Xpress (Survei pada followers Instagram Ninja Xpress)”. Penelitian ini dilakukan untuk mengetahui seberapa besar pengaruh kualitas pelayanan terhadap citra perusahaan pada jasa pengiriman Ninja Xpress.

Alasan penulis memilih followers Instagram Ninja Xpress sebagai responden karena penulis menganggap bahwa followers Instagram Ninja Xpress sebagian merupakan pengguna yang pernah memakai jasa Ninja Xpress dan penulis seringkali melihat interaksi antara admin Ninja Xpress dengan customernya sehingga penulis menganggap dengan seringnya interaksi customer service dengan pengguna Ninja Xpress, penulis melihat ke-efektifan Instagram Ninja Xpress dalam membalas keluhan dan kebutuhan customer melalui kolom komentar dan DM (direct message).

Dari pelayanan Ninja Xpress tersebut, penulis ingin mengetahui dan mengukur seberapa besar pengaruh kualitas pelayanan yang diberikan oleh Ninja Xpress. Penulis menggunakan variabel $\mathrm{x}$ (kualitas pelayanan), Parasuraman (dalam Purnama, 2006:19) mengatakan bahwa kualitas pelayanan adalah perbandingan antara pelayanan yang dirasakan pelanggan dengan kualitas pelayanan yang diharapkan pelanggan. Kualitas pelayanan menjadi cerminan dari suatu perusahaan karena jika kualitas pelayanannya baik, maka akan timbul persepsi positif yang muncul dari testimoni pelanggan, dengan begitu pelanggan akan mendifusi perihal layanan perusahaan tersebut kepada orang lain atau orang-orang terdekatnya. Dengan melakukan hal tersebut, akan membentuk suatu citra dari perusahaan tersebut berdasarkan pengalaman pelanggan dan berdasarkan apa yang telah dilakukan perusahaan tersebut kepada pelanggan. Hal tersebut disajikan kedalam dimensi yang akan diturunkan menjadi indikator. Dengan begitu, penulis dapat melihat tanggapan yang diberikan responden dalam sajian yang berwujud google form.

Kualitas pelayanan berpusat pada upayaupaya dalam pemenuhan kebutuhan dan keinginan dari pelanggan serta ketepatan penyampaiannya untuk mengimbangi harapan dari pelanggan 
(Tjiptono, 2005:59). Menurut Parasuraman yang dikutip oleh Tjiptono (2011:198) kualitas pelayanan harus dirancang dan diukur dengan memperhatikan bukti fisik, reliabilitas, ketanggapan, jaminan, dan kepedulian.

Hal yang berkenaan dengan bukti fisik adalah fasilitas fisik yang dimiliki perusahaan dan penampilan karyawan yang rapi, perusahaan dapat mencuri perhatian customer dengan memiliki karyawan yang rapi dan berseragam serta peralatan atau atribut yang lengkap. Reliabilitas berkaitan dengan kemampuan perusahaan untuk memberikan pelayanan yang akurat sejak pertama kali. Maksud dari hal tersebut adalah perusahaan harus konsisten dan bertanggung jawab atas pelayanan yang diberikan serta harus sesuai dengan janji-janjinya kepada customer. Ketanggapan berhubungan dengan kesediaan dan kemampuan karyawan untuk membantu konsumen. Perusahaan jasa yang memiliki customer service harus dapat memberikan waktunya untuk membantu konsumen dalam menangani segala permasalahan, karena hal tersebut dapat menumbuhkan keamanan dan kenyamanan yang membuat customer berlangganan. Lalu ada jaminan yang mencerminkan perilaku seorang karyawan yang mampu menumbuhkan kepercayaan konsumen. Jaminan diperlukan perusahaan untuk mencapai kesuksesan. Jaminan juga berarti bahwa karyawan harus selalu sopan dan menguasai pengetahuan dan permasalahan. Terakhir, terdapat kepedulian yang menyatakan bahwa perusahaan memahami masalah konsumen, lalu bertindak. Hal ini dirasakan customer pada saat menggunakan Ninja Xpress karena customer service Ninja Xpress memberikan perhatian yang tulus meliputi kemudahan dalam melakukan komunikasi antara customer dan customer service serta memperhatikan segala keluhan dan kebutuhannya.

Variabel Y yang digunakan penulis adalah citra perusahaan. Citra perusahaan menurut Jasfar (2009:184) adalah sebagai representasi penilaianpenilaian dari konsumen, baik konsumen yang potensial maupun konsumen yang kecewa. Konsumen biasanya akan memberikan testimoni setelah menggunakan jasa pada suatu perusahaan, jika terstimoninya memberikan tanggapan yang positif, maka citra tersebut akan dikenal dengan baik. Menurut Iman (2010) terdapat tiga hal penting dalam citra, yaitu kesan obyek, proses terbentuknya citra, dan sumber terpercaya. Obyek meliputi individu maupun perusahaan yang terdiri atas sekelompok orang di dalamnya. Citra dapat terbentuk dalam memproses informasi yang tidak menutup kemungkinan terjadinya citra pada obyek dari adanya penerimaan informasi setiap waktu.

Citra perusahaan memiliki dimensi yang perlu diperhatikan, yaitu; quality, performance, responsibility, dan attractiveness. Quality berhubungan dengan kualitas produk atau jasa perusahan. Kualitas suatu jasa atau produk perlu diperhatikan demi keberlangsungan suatu perusahaan dengan selalu memiliki inovasi dan kreatif untuk membangun perusahaan menjadi lebih baik. Perfomace berhubungan dengan perusahaan memiliki kesempatan untuk terus tumbuh dan berkembang. Perusahaan akan terus tumbuh dan berkembang jika kinerja karyawannya 
baik dan selalu diperhatikan. Karyawan harus diberi apresiasi jika berprestasi dan melakukan pekerjaannya dengan baik agar menumbuhkan rasa semangat pada diri karyawan yang akan memunculkan kepercayaan dirinya untuk terus berkembang dan berinovasi. Berikutnya, ada responsibility yang berhubungan dengan kepedulian terhadap lingkungan. Hal ini merupakan keharusan suatu perusahaan untuk melakukan kegiatan sosial agar karyawan mendapatkan pengalaman baru dan perusahaan dapat menyampaikan tujuan seta visi misinya kepada orang-orang yang dituju melalui kegiatan sosial. Terakhir, ada attractiveness mencakup citra perusahaan yang dibangun oleh karyawannya. Perusahaan harus memiliki karyawan yang berkinerja baik untuk mendapatkan perhatian dari masyarakat.

Model pembentukan citra merupakan model yang menggambarkan input-output, proses intern dalam model ini adalah pembentukan citra, sedangkan input adalah stimulus yang diberikan dan output adalah tanggapan atau perilaku tertentu (Soemirat dan Ardianto, 2010:116). Citra itu sendiri digambarkan melalui persepsi-kognisimotivasi-sikap. Input dalam penelitian ini adalah kualitas pelayanan, sedangkan proses intern-nya adalah customer, dan output-nya merupakan citra perusahaan. Proses pembentukan citra pada akhirnya akan menghasilkan sikap, pendapat, tanggapan atau perilaku tertentu. Berdasarkan data penelitian yang dikumpulkan menggunakan kuesioner melalui google form, peneliti melihat terbentuknya citra perusahaan di mata customer berdasarkan pengalaman sehingga timbul persepsi, kognisi, motivasi, sikap dari customer itu sendiri. Artinya, persepsi-kognisi-motivasi-sikap customer yang timbul karena kualitas pelayanan yang didapat oleh customer, terbukti akan mempengaruhi citra perusahaan tersebut.

Penelitian ini menunjukkan bahwa untuk membentuk citra yang baik di mata customer, perusahaan harus memperhatikan faktor-faktor pembentukan citra salah satunya adalah Actual experience. Actual experience adalah pengalaman yang langsung dirasakan oleh pelanggan dalam mengkonsumsi barang dan jasa. Dari pengalaman tersebut akan menghasilkan persepsi-kognisimotivasi-sikap yang kemudian akan menentukan citra perusahaan tersebut. Hal ini menunjukkan bahwa semakin tinggi atau semakin baik kualitas jasa (tangible, reliability, responsiveness, assurance, dan empathy), maka semakin baik pengalaman yang didapat oleh pelanggan dan semakin baik pula citra perusahaan di mata customer.

Berdasarkan hasil penelitian yang telah dilakukan, dapat diketahui bahwa terdapat hubungan yang sangat kuat dan berpengaruh antara kualitas pelayanan terhadap citra perusahaan. Hubungan yang sangat kuat ini memiliki arti bahwa customer merasakan kualitas pelayanan yang diberikan Ninja Xpress sesuai dengan harapannya serta customer service selalu sigap dalam menangani masalah dan kebutuhan customer sehingga terjadi hubungan yang sangat kuat.

Pada penelitian ini, populasi yang digunakan peneliti adalah followers Instagram 
@ NinjaXpress, populasi yang diambil pada tanggal 19 November 2019 pukul 20.58 WIB berjumlah 16.700 followers. Penarikan sampel yang digunakan dalam penelitian ini adalah janis nonprobability, yaitu purposive sampling. Kriteria responden yang dapat mengisi kuesioner adalah followers akun Instagram @NinjaXpress, pernah menggunakan jasa Ninja Xpress. Jumlah sampel adalah sebanyak 99,40 yang peneliti bulatkan menjadi 99 orang yang telah dihitung menggunakan rumus Yamane. Setelah peneliti mendapatkan 99 responden yang sesuai dengan kriteria yang telah ditetapkan sebelumnya, maka hasil data yang diperoleh akan dihitung. Dalam pembahasan ini akan menjelaskan mengenai pengaruh antara Variabel X (Kualitas Pelayanan) terhadap Variabel Y (Citra Perusahaan).

Penjelasan ini dapat dibuktikan pada hasil uji koefisien determinasi yang menyatakan bahwa sebesar $67,4 \%$ citra perusahaan (variabel Y) ditentukan oleh pengaruh kualitas pelayanan (Variabel X), dan sisanya yaitu sebesar 32,6\% ditentukan oleh faktor lain yang tidak disertakan dalam penelitian ini. Berdasarkan analisis jawaban responden, diketahui bahwa responden yang terlibat dipenelitian ini sebanyak 65 responden berjenis kelamin perempuan dan 34 responden berjenis kelamin laki-laki yang berarti dalam penelitian ini jumlah reponden perempuan lebih banyak dibandingkan responden laki-laki, dan dari 99 responden, 48 responden diantaranya berusia 21-25 tahun.

Berdasarkan hasil uji korelasi antara dua variabeldengan menggunakan SPSS for windows versi 25, maka dapat dijelaskan bahwa adanya korelasi antara kedua variabel tersebut, nilai koefisien $\mathrm{r}$ yaitu $=0,821$ dan nilai tersebut menjelaskan bahwa terdapat hubungan yang sangat kuat karena terletak diantara angka 0,800 - 1,000. Hasil hipotesis perhitungan $\mathrm{t}$ hitung 14,184>t tabel 1,661, maka dapat disimpulkan Ho ditolak dan Ha diterima yang berarti bahwa semakin kuat kualitas pelayanan maka semakin kuat mempengaruhi citra perusahaan Ninja Xpress. Dengan demikian dapat disimpulkan terdapat pengaruh yang signifikan antara kualiatas pelayanan terhadap citra perusahaan Ninja Xpress.

\section{SIMPULAN}

Berdasarkan hasil penelitian dan pembahasan mengenai kualitas pelayanan terhadap citra perusahaan dapat ditarik kesimpulan bahwa hasil uji t-hitung sebesar 14,184 dengan nilai signifikasi 0,10 . Dengan hasil ini keputusan yang diambil adalah menolak Ho dan menerima Ha yang berarti bahwa terdapat pengaruh yang signifikan dari customer service melalui pelayanan yang diberikan kepada pelanggannya.

\section{DAFTAR PUSTAKA \\ BUKU}

Abdurrachman, O. 1968. Dasar-dasar Public Relations. Bandung: PT Citra Aditya Bakti

Adona, F. 2006. Citra dan kekerasan dalam iklan perusahaan di televisi. Padang: Andalas University Press.

Alma, B. 2007. Manajemen Pemasaran dan Pemasaran Jasa. Bandung: CV Alfabeta. 
Arikunto, S. 2013. Prosedur Penelitian: Suatu Pendekatan Praktik. Jakarta: Rineka Cipta.

Cangara, H. 2011. Pengantar Ilmu Komunikasi. Jakarta: PT RajaGrafindo.

Cutlip, S. (2009). Effective Public Relations. Jakarta: Kencana.

Firsan, N. (2009). Crisis Public Relations. Jakarta : Grasindo

Griffin. 2005. Manajemen Kualitas : Penerapan Konsep-Konsep Kualitas Dalam Manajemen Bisnis Total. Jakarta : PT. Gramedia Utama

Irawan, H. 2005. Costumer Satisfaction. Yogyakarta : BPFE.

Tjiptono, F. 2007. Strategi Pemasaran. Yogyakarta: Andi Offset.

Marhaeni, F. 2009. Ilmu Komunikasi Teori Dan Praktik. Yogyakarta: Graham Ilmu

Melewar, T. 2008. Facets of Corporate Identity, Communication, and Reputation. New York: Routledge

Nasrullah, R. 2015. Media Sosial; Persfektif Komunikasi, Budaya, dan Sosioteknologi. Bandung : Simbiosa Rekatama Media

Purnama, N. 2006. Manajemen Kualitas Perspektif Global. Edisi Pertama Yogyakarta: EKONISIA.

Ruslan, R. 2008. Metode Penelitian Public Relations dan Komunikasi. Jakarta: PT. Raja Grafindo Persada.

Sujarweni, W. 2014. Metodologi penelitian: Lengkap, praktis, dan mudah dipahami. Yogyakarta: PT Pustaka Baru
Tjiptono. 2008. Pemasaran Strategik. Yogyakarta : Penerbit Andi

Ulber, S. 2009. Metode Penelitian Sosial. Bandung: PT. Refika Aditama

Martono, Nanang. 2011. Metode Penelitian Kuantitatif. Jakarta: PT Raya Grafindo Persada.

\section{JURNAL}

Akkas, N. 2016. Pengaruh komunikasi pemasaran terpadu terhadap citra perusahaan dan dampaknya terhadap kepuasan pelanggan membeli mobil pada PT. Hadji Kalla cabang Palu. E-Jurnal Katalogis, 4, 24-36. Diakses dari

http://jurnal.untad.ac.id/jurnal/index.php/Katal ogis/article/view/6505/5186, pada tanggal 4 November 2019, jam 19.00 WIB.

Khoirista, A., Yulianto, E., \& Mawardi, K. 2015. Pengaruh kualitas pelayanan terhadap kepuasan pelanggan. Jurnal Administrasi Bisnis, 25, 1-7. Diakses darihttp://administrasibisnis.studentjournal.ub. ac.id/index.php/jab/article/view/1000/1182, pada tanggal 45November 2019, jam 16.00 WIB.

Kuntari, B., Kumadji, S., \& Hidayat, K. 2016. Pengaruh kualitas pelayanan terhadap kepuasan dan loyalitas pelanggan, Jurnal Administrasi Bisnis, 36, 196-202. Diakses dari http://administrasibisnis.studentjournal.ub.ac.i d/index.php/jab/article/view/1417/1882, pada tanggal 5 November 2019, jam 17.00 WIB.

Pramana, I., Rastini, N. (2016). Pengaruh kualitas pelayanan terhadap kepercayaan nasabah dan loyalitas nasabah bank mandiri cabang veteran Denpasar Bali.E-Jurnal Manajemen, 5, 706731. Diakses dari https://ojs.unud.ac.id/index.php/Manajemen/ar 
$\underline{\text { ticle/view/18248/11928, }}$ pada tanggal 5 November 2019, jam 19.00 WIB.

Rivai, A., Suneni, \& Febrilia, I. (2019). Pengaruh kualitas pelayanan, harga, dan citra merek terhadap kepuasan konsumen pengguna transportasi ojek online grab. Jurnal Riset Manajemen Sains Indonesia, 10, 204-225. Diakses dari http://journal.unj.ac.id/unj/index.php/jrmsi/arti cle/view/11034/6858, pada tanggal 6 November 2019, jam 13.00 WIB.

\section{WEBSITE}

www.websindo.com diakses pada tanggal 15 Oktober 2019, jam 16.00 WIB.

www.techinasia.com diakses pada tanggal 1 November 2019, jam 12.00 WIB.

Www.mediakonsumen.com diakses pada tanggal 1 November 2019, jam 15.00 WIB. 